\title{
Cusseque - Landscape
}

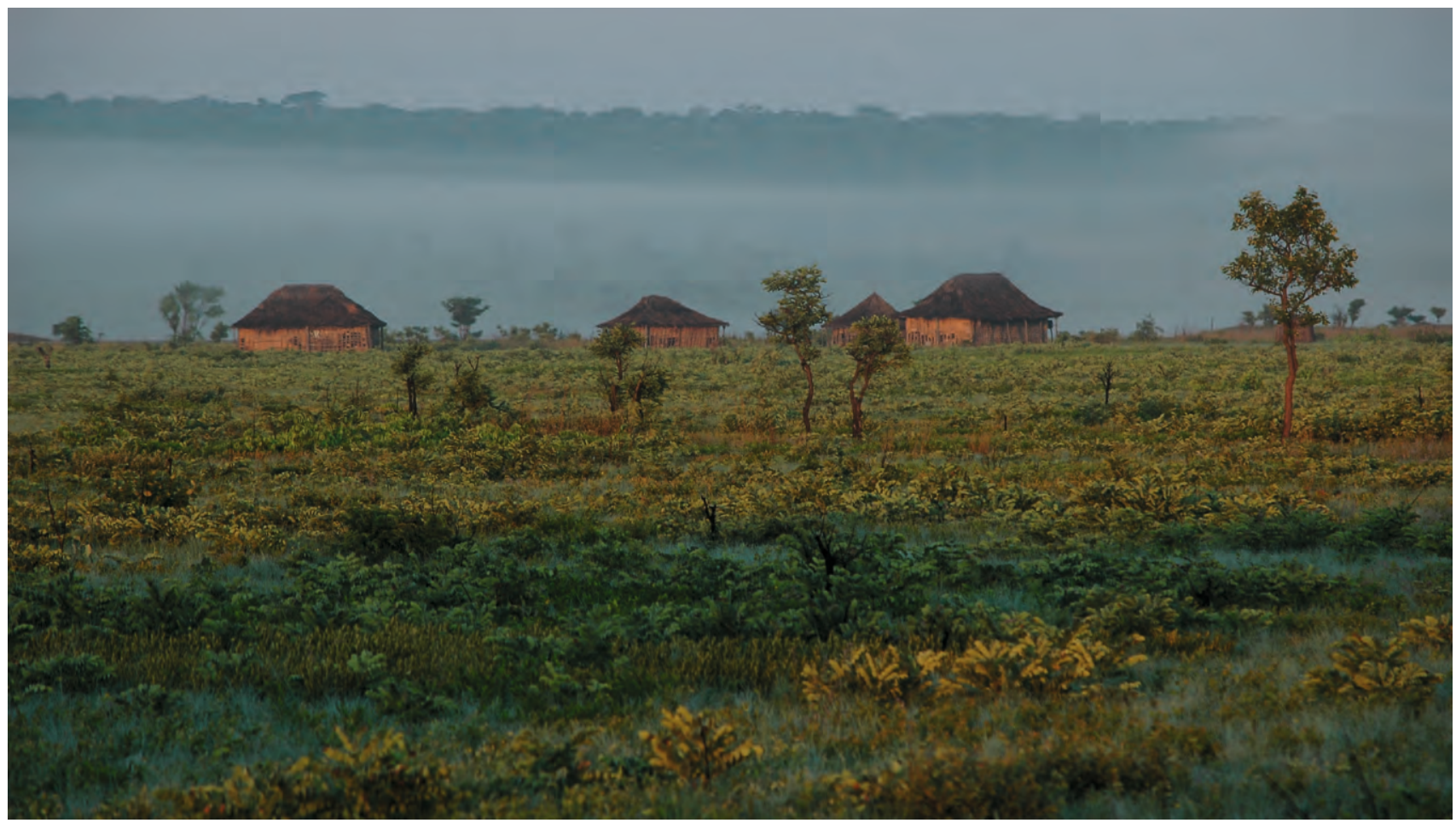

Fig. 1: Morning clouds lifting from the sandy plains in the Cusseque Valley (photo: M. Finckh).

Table 1: Landscape characteristics.

\begin{tabular}{|c|c|c|}
\hline Geology & & Lithology \\
\hline Precambrian basement \& Pleistocene Kalahari sands & & Weathered Granites \& unconsolidated sands \\
\hline Mean height (m a.s.I.) & & Mean annual precipitation \\
\hline $1,575 \mathrm{~m}$ & & $987 \mathrm{~mm}$ \\
\hline \multicolumn{3}{|l|}{ Landscape units (LSU) } \\
\hline $\begin{array}{l}\text { LSU } 1 \\
\text { (Wetlands and Streams): } 7 \%\end{array}$ & $\begin{array}{l}\text { LSU } 2 \\
\text { (Slopes): } 30 \%\end{array}$ & $\begin{array}{l}\text { LSU } 3 \\
\text { (Summits): 63\% }\end{array}$ \\
\hline \multicolumn{3}{|l|}{ Related land uses } \\
\hline $\begin{array}{l}\text { fishery, horticulture, washing, } \\
\text { hunting }\end{array}$ & hunting, grazing & $\begin{array}{l}\text { slash-and-burn agriculture, bee-keeping } \\
\text { charcoal production, hunting, grazing, } \\
\text { extraction of construction material, } \\
\text { homestead during cultivation time }\end{array}$ \\
\hline \multicolumn{3}{|l|}{ Ecosystem goods } \\
\hline $\begin{array}{l}\text { vegetables, drinking water, } \\
\text { fish, wildlife, meat }\end{array}$ & meat, wildlife & $\begin{array}{l}\text { maize, cassava, beans, fire wood, } \\
\text { charcoal, timber, honey, wildlife }\end{array}$ \\
\hline
\end{tabular}

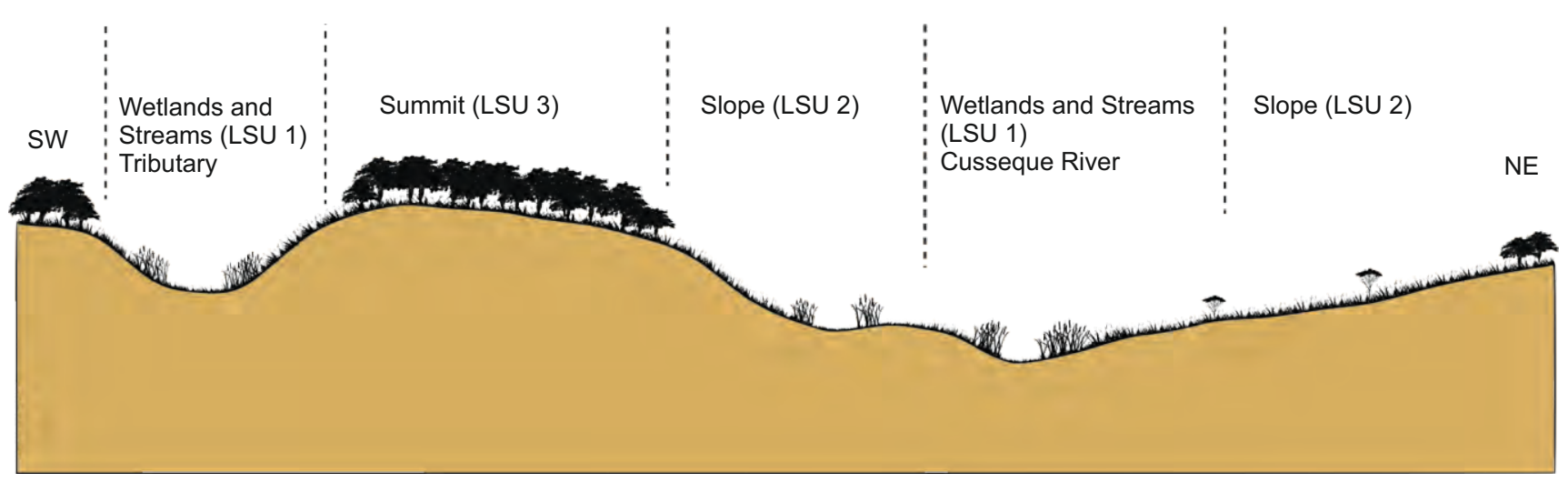

Fig. 2: Landscape catena of the core site Cusseque. 


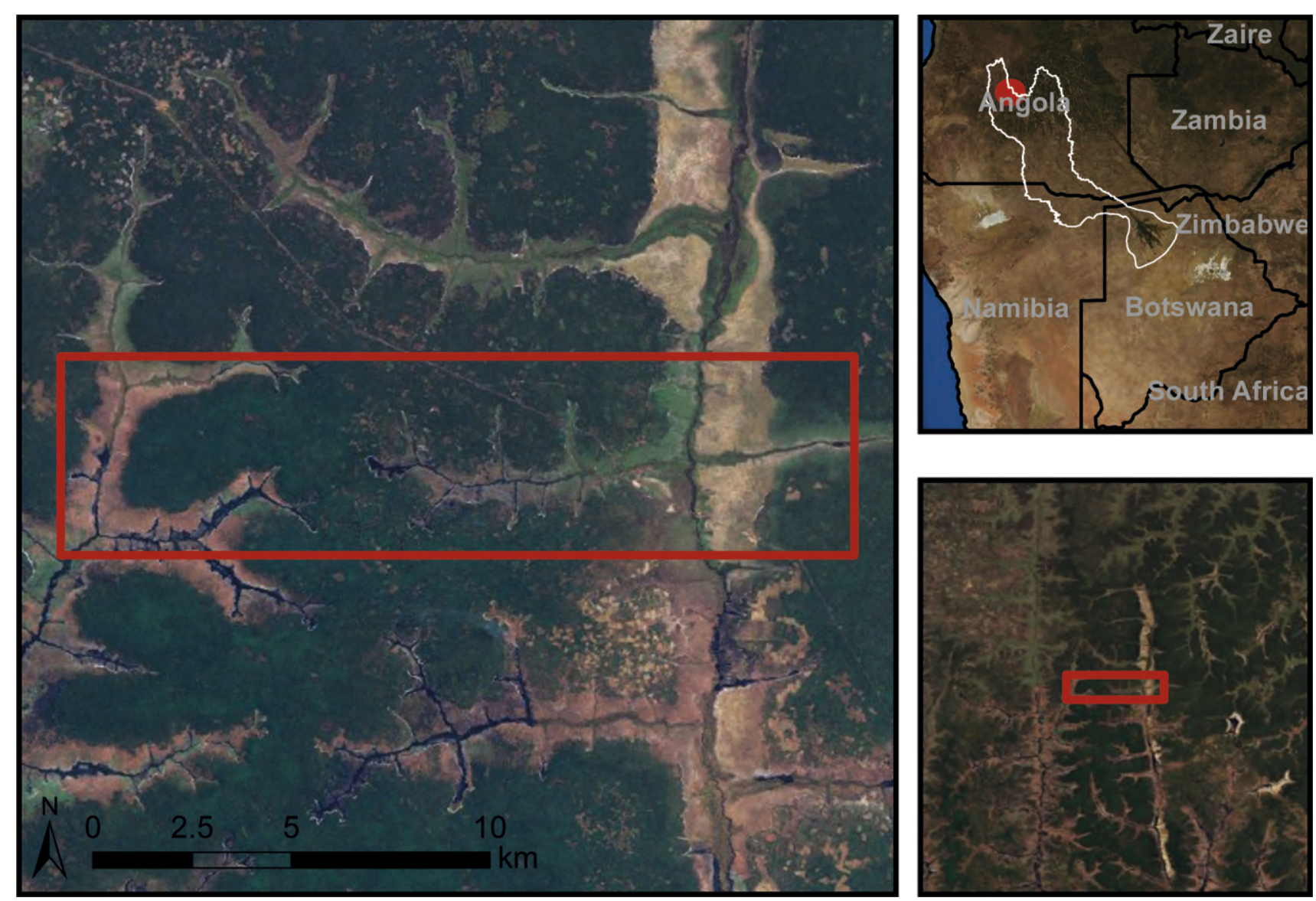

Fig. 3: Cusseque core site at three scales. The white line depicts the Future Okavango Research Area (FORA) (background: Esri, DigitalGlobe, GeoEye, i-cubed, USDA, USGS, AEX, Getmapping, Aerogrid, IGN, IGP, swisstopo, and the GIS User Community).

The geological structure of the precambrian Angolan Plateau shapes the landscape (Fig. 1) of the upper parts of the Okavango Catchment. Weathering and erosion processes along the fissure lines have left a rolling landscape with a perpendicular drainage system. Main river lines run from north to south with first and second order tributaries perpendicular to each other (Fig. 2 and 3). The height differences between the main rivers - here the Cusseque River and the summits are about $100 \mathrm{~m}$. The valley of the Cusseque River has a wide fossil river terrace with sandy alluvial deposits while the tributaries show $\mathrm{v}$-shaped valleys incised in the weathered granitic bedrock.

Hills and upper slopes were originally covered by dense Miombo forests; nowadays in large areas they are disturbed by shifting cultivation. Mid- and footslopes as well as the fossil sandy terraces of the Cusseque River are covered by open vegetation whereas the lowest parts of the valley bottoms are covered by peatlands.

Three main landscape units are distinguished (Tab. 1): Wetlands and
Streams (LSU 1) being composed of open water bodies, peatbogs with peat layers exceeding $1 \mathrm{~m}$ and, at the head of the tributary valleys, temporary water logged areas on mineral soil. Cyperaceae form the dominant element of the vegetation of the peatbogs. This landscape unit follows the drainage lines, forming a more or less narrow belt around them. The peatlands are often bounded by a band of bleached white sand with sparse vegetation.

The Slopes (LSU 2) comprise two different subunits with regard to soil and vegetation. The fossil river terraces of the Cusseque River extend between wetlands and hills on the eastern side of the river. Large deposits of bright whitish sand, most likely transported from the currently decapitated upper reaches of the Cusseque Catchment, form extended intermediate and slightly sloping plains along the main valley. Grasses and woody suffrutices dominate the vegetation on the sandy plains.

More typical for the area is the western part of the valley where dwarf shrubs with huge underground biomass (geoxylic suffrutices) are dominant on reddish and often shallow soils. On the upper slopes, the open grassland changes along a gradient of micro-climate and fire impact from open to close Miombo woodlands.

If not in agricultural use, the Summits (LSU 3) are covered with dense semideciduous forests with heights of up to $15 \mathrm{~m}$ dominated by tree species of the genera Brachystegia, Cryptosepalum and Julbernardia. During the rainy season, the hills are preferred areas for slash-and-burn agriculture with the main crops of maize and cassava, whereas the peatlands serve as areas for the cultivation of vegetables during the dry season. The river terraces are used for cattle grazing and hunting; up to now the number of cattle is very low.

\section{Acknowledgements}

This study was funded by the BMBF (The Future Okavango project). For details see authors' general acknowledgements in this volume.

Responsible authors: A. Groengroeft, J. Luther-Mosebach, L. Landschreiber, R. Revermann, M. Finckh, A. Eschenbach 